\title{
- Post-Earnings Announcement Drift in Greece
}

\author{
William Forbes* \\ Waterford Institute of Technology \\ Cork Road, Waterford, Ireland \\ williampforbes@icloud.com

\section{George Giannopoulos} \\ Kingston Business School \\ Kingston University, Kingston Hill \\ Kingston Upon Thames, London, KT2 7LB, England \\ g.giannopoulos@kingston.ac.uk
}

Published 17 August 2015

This paper presents evidence regarding the post-earnings announcement drift (PEAD) anomaly for the Greek market in the years 2000-2006 (covering earnings announcements in the years 2001-2007). The impact of the introduction of International Financial Reporting Standards on the size and prevalence of the PEAD anomaly is examined. Unlike recent evidence for the US market we find PEAD to be alive and well, and of growing importance in our Greek sample. It may be the adoption of international financial reporting standards (IFRS) has served to reduce earnings predictability in Greece and thus enhance PEAD in the Athens stock exchange (ASE) market. This contrasts strongly with US evidence that the postearnings-announcement drift anomaly is now waning as more efficient markets and smarter, fundamentals-based, traders arbitrage its impact on stock prices.

Keywords: Post-earnings announcement drift; informational efficiency; emerging markets; IFRS implementation.

\section{Introduction}

Post-earnings announcement drift (PEAD) is an anomaly "above suspicion" according to Fama (1998). But we might ask is it particularly strong at times when the market is spectacularly uncoupled from value or in markets that

*Corresponding author. 
have particularly sparse information environments, where such a failure to impound key indicators of value might be observed? This question leads us to examine PEAD in the Athens Stock Exchange (ASE) in the financial years 2000-2006 (resulting in the earnings announcement dates in the years 2001-2007), a case-study that seems to fit this description. So, this paper is a case-study of an anomaly already well-documented amongst major centers of financial trading such as New York (Bernard and Thomas, 1989, 1990; Bernard, 1993) and London (Liu et al., 2003). A study of the Cypriot market was motivated by similar concerns and reported results rather similar to our own (see Vafeas et al., 1998). Liu et al. (2012) present evidence of the effect of international financial reporting standards (IFRS) compliance on the value relevance of earnings in Peru. Here, we focus on the PEAD anomaly in the Greek market in a era of radical accounting change and report a resurgence in PEAD compared to that observed in an immediately prior period. Our results suggest PEAD may be reviving, in southern Europe at least, just as reports of its death are being made in more developed markets, like the US and UK. We link this revival to the process of IFRS implementation since 2005 and the resulting diminution of earnings-smoothing in favor of IFRS which favors a more volatile earnings stream of the type produced by "fair value" accounting and its requisite frequent asset revaluations.

\section{Motivation and Context}

\subsection{The PEAD anomaly}

Ever since PEAD's first arrival as a stock market anomaly (Ball and Brown, 1968) the inability of investors to adequately interpret earnings troubled both academics and accounting reformers alike. An investment community which proves incapable of interpreting earnings numbers is likely to exhibit informational inefficiency more generally. For the US financial market Cohen et al. (2007) report a decline in the risk premium paid to trading on earnings announcements after 1988, suggesting that various academic papers pointing out the PEAD anomaly have served to stimulate arbitrage to reduce its size. Such a decline in the risk-premia awarded for assuming earnings-announcement day volatility in the stock price makes sense given the much better disclosure environment of recent years with increased voluntary disclosure, earnings "guidance", including conference calls which are often transmitted live and then posted on the Web. The Greek market may provide an environment where limits exist upon effective arbitrage and the greater scale of "noise-trading" may allow such earnings-based pricing 
anomalies to continue to flourish even as they wane in the most developed centres of securities trading.

The Greek market in the years 2001-2007 certainly fulfils this requirement of a highly uncertain environment both with regard to what Greek stocks were worth and how earnings might be used to infer their value. As such the adoption of IFRS might be seen as a way to ameliorate information uncertainty and hence reduce the strength of observed PEAD in the Greek market. But, as we point out the nature of the transition to IFRS accounting means the earnings of Greek companies have become more volatile, and less predictable, inducing more marked PEAD in the ASE market.

\subsection{Why Greece?}

Karampinis and Hevas (2011) present evidence suggesting that the introduction of IFRS has had limited impact on the informativeness of earnings in the "unfavorable environment" of Greece. Bhattacharya et al. (2003) report Greece ranks in the least transparent group on all three earnings quality metrics they use, earnings aggressiveness, loss-avoidance and earnings smoothing. Our study of PEAD thus focusses on Greece where casual empiricism suggests sentiment may have had a large role in equity prices during a speculative market period. Prior research already suggests the Greek market may be inefficient in the weak-form sense (Dokery and Kavassanos, 1995). One aspect of this informational inefficiency may well concern the processing of earnings information.

Greek companies appear to engage in some of the most extreme earnings manipulation practices in the world. Leuz et al. (2003) argue that this world-beating level of earnings management derives from high private benefits control, acquired under a legal regime where investor protection by the law is weak. Dasilas and Leventis (2011) confirm that the closely held nature of ASE constituents means they have little need to signal value to outside shareholders unrepresented on the Board. Our discussions with market professionals in the Greek market confirm minority shareholder rights, especially in the face of an entrenched family interest, are weak. Often the lack of effective regulation to control insider trading appears to induce slightly conspiratorial ambiance to the "Sophokleous Street" culture in Athens. ${ }^{1}$ Bird et al. (2014) confirms the role of market sentiment in intensifying PEAD in the US markets and Kao (2007) provides evidence

\footnotetext{
${ }^{1}$ The term is Greek equivalent of Wall Street in the US.
} 
that unsophisticated investors are less able to detect the effect of accruals management on future earnings outcomes.

The informativeness and quality of earnings disclosure is not solely determined by accounting standards alone, but by their enforcement which is critical (Pope and McLeay, 2011). To adopt but not enforce is simply a form of "psuedo-adoption" that investors often see through (Daske et al., 2008).

Verriest et al. (2013) present evidence that early and effective compliance is associated with good corporate governance that facilitates the enforcement of high-quality disclosure. Well-governed companies make more and higher quality disclosures, while political interference in the adoption process tends to induce opportunistic usage of disclosures.

Greece has both a relatively poor record on corporate governance and a long history of politicising both the structure and practice of the accounting profession (Caramanis, 1999). This suggests a form of "psuedo-adoption" of IFRS standards may well be the reality of Greek accounting practice. Florou and Argiris (2007) present evidence on the poor quality of Greek corporate governance against a variety of benchmarks. Greek companies have poor and opaque corporate governance, especially when compared on an international basis. So, earnings information is often evaluated within a poorer broader institutional framework of corporate accountability in Greece.

Boonlert U-Thai et al. (2006) construct a sort of portmanteau metric of "earnings quality" based on four separate, but related, properties of earnings and the extent to which these properties can presage future cash-flows and so anticipate valuation changes. Greece ranks about 20th for accrual quality, earnings persistence and earnings predictability in their earnings quality ranking, but sixth for earnings smoothness, although the effectiveness of such smoothing is unclear (Wang, 2014).

This combination of relatively persistent earnings, which displays evidence of some moderate smoothing, makes the Athens Exchange an interesting one in which to examine PEAD and how its nature is changing over time in response to what has been an era of fairly dramatic accounting reform. Boonlert U-Thai et al. relate the earnings characteristics they study to the degree to which a nation protects minority investors rights. Boonlert U-Thai et al. place Greece in their third cluster as a codified (as opposed to common) law system of French origin, alongside countries more typically seen as still developing/emerging, as opposed to mainstream European markets. Empirical work by Athianos et al. (2005) concerning the implementation of IFRS in Greece has confirmed the impact of IFRS implementation in shifting the balance of financial reporting from very conservatively 
reported earnings towards more of a "fair-value" balance sheet perspective with all the earnings volatility that implies. The authors find their results are:

"consistent with Greek GAAP conservativeness and an income smoothing orientation and with IAS's fair value and balance sheet orientation" (Athianos et al., 2005, p. 23).

This conservatism in reporting profit reflects the historical link between reported and taxable profit under Greek GAAP. IFRS implementation disrupts this historic settlement.

Related work by Vazakidis and Athianos (2010) chronicling IFRS compliance, by a group of 90 companies traded on the ASE index in the years 2005-2006, show how ASE constituents reflect the greater volatility of earnings, induced by "fair-value" revaluations of newly IFRS complaint balance sheets, in their pricing behavior. Their study uncovers

"key differences between the old Greek conservative accounting and the fair value accounting of IFRS using a mixture of studies, the current paper has proved that the switch of the accounting regime from Greek accounting to IFRS has affected the valuation of companies" (Vazakidis and Athianos, 2010, p. 111).

It is this decline in the predictability of earnings, following the implementation of IFRS, that makes the Athenian market an interesting one where IFRS may of increased the quality of earnings, but reduced their predictability.

\section{Research Method and Data Sources}

The Athenian market is characterized by a number of informational inefficiencies which include

- larger transaction costs to trading, thicker bid-ask spreads and trading commissions as well as taxes levied on trades and profits made on them (Phylaktis et al., 1999),

- insider trading and therefore "leakage" of information prior to the earnings announcement date (Baralexis, 2008).

We study a sample of earnings announcements taken from the financial years 2000-2006. This results in earnings announcement dates spread across 
months in early 2001 to early 2007. This is a sample period surrounding the introduction of IFRS in 2005 and before the current sovereign debt crisis took hold of the Greek economy, pushing all stock markets down.

\subsection{Earnings surprises}

We measure earnings "surprises" using two alternative metrics which are:

- A time-series benchmark based on deviations from last year's earnings value.

- A benchmark based on the deviation of reported earnings from the most recent monthly consensus forecast of earnings.

So the earnings "surprise" $(S)$ for the $i$ th company in year $t$ is defined using two benchmarks. The first, the time-series benchmark, is simply

$$
S_{i, t, k=1}=\frac{\left(X_{t, i}-X_{t-1, i}\right)}{P_{t-10, i}}
$$

and the second, the analysts' forecasts benchmark, is given by

$$
S_{i, t, k=2}=\frac{\left(X_{t, i}-E_{t-1, i}\left[X_{t, i}\right]\right)}{P_{t-10, i}},
$$

where the two expectation formation models $(k=1$ or 2$)$ of earnings $(X)$, denoted by the superscript on the expectation operator, are substituted into the two alternative earnings surprise metrics, $E_{t-1, i}\left[X_{t, i}\right]$ is the consensus forecast of next month's earnings figure formed at $t-1$ and, finally $P_{t-10, i}$ is the price of the $i$ th stock 10 days prior to the earnings announcement.

Earnings announcement dates for the Athens market were collected from the Website of the ASE. ${ }^{2}$ There is no requirement for preliminary earnings announcements to appear on newswire services, etc, so the date of publication of the accounts and the earnings-per-share figure are coincident in the Athenian market.

\subsection{Investor returns and abnormal return benchmarks}

Measuring abnormal returns in an "event" study of PEAD is always a controversial issue. In this, we follow a now well-established research method attributable to Barber and Lyon (1997) and Lyon et al. (1999).

\footnotetext{
$\overline{{ }^{2} \text { http://www.ase.gr/content/gr/announcements/companiespress/. }}$
} 
The abnormal share price performance metric employed is a buy-and-hold return measure defined as follows:

$$
R_{p, s, t}^{b h}=\sum_{i=1}^{n_{s}} \frac{\left[\prod_{t=s}^{s+\tau}\left(1+\epsilon_{i, t}\right)\right]-1}{n_{s}},
$$

where $n_{s}$ is the number of companies in the portfolio with return $R_{p, s, t}$ on the day $s$ over some horizon $\tau$, where the portfolio return $R_{p, s, t}$ is defined over its individual constituents abnormal returns $\epsilon_{i, t}$. To examine PEAD in our sample we construct this metric for a sample of companies receiving good and bad news about earnings as indicated by a chosen earnings benchmark.

We employ standard returns benchmarks. Initially, we use market-adjusted returns, $R_{i t}-r_{m t}$, defining $R_{i t}$ to be the individual stock return and $r_{m t}$ to be the daily return on the ASE index, as an alternative measure of $\epsilon_{i, t}$. Second, we use the now fairly standard controls for risk outlined by Fama and French (1993) in the form of their 3-factor model given by the equation

$$
R_{i t}-R_{f t}=\alpha_{i, t}+\beta_{i}\left(R_{m t}-R_{f t}\right)+s_{i} \mathrm{SMB}_{t}+h_{i} \mathrm{HML}_{t}+\epsilon_{i t},
$$

where SMB is the monthly premia/discount payable to investing in shares in the smallest sample size quartiles, when ranked by market capitalization, as against the largest. HML is the premia/discount payable to companies in the lowest market to book ratio quartile versus the highest. The usual CAPM/ SML market risk factor $\left(R_{m t}-R_{f t}\right)$ remains in the model. Here, the constant term $\alpha_{i, t}$ represents a measure of company under/out performance in each period relative to the 3-factor benchmark, a sort of 3-factor Jensen's $\alpha$.

\section{Data}

We study 520 earnings announcements drawn from 165 separate Greek companies in fiscal years 2001-2007. Figure 1 gives a plot of the ASE index for the years 2000-2007 and sets the context for later tests. There is a clear point of recovery March 2003 onwards. We choose our starting point deliberately to exclude the most wild excesses of the technology boom in the period up until April 2000. Much of this positive sentiment arose from the prospects of greater integration into the EU and specifically membership of the Eurozone from the start of $2002 .^{3}$ So, it can be hard to disentangle stock market responses to IFRS adoption and broader marketwide enthusiasm towards European membership in our sample period. For this reason good benchmarking of asset returns is crucial.

\footnotetext{
${ }^{3}$ Greece qualified for membership in 2000, but was then admitted early in 2001 .
} 


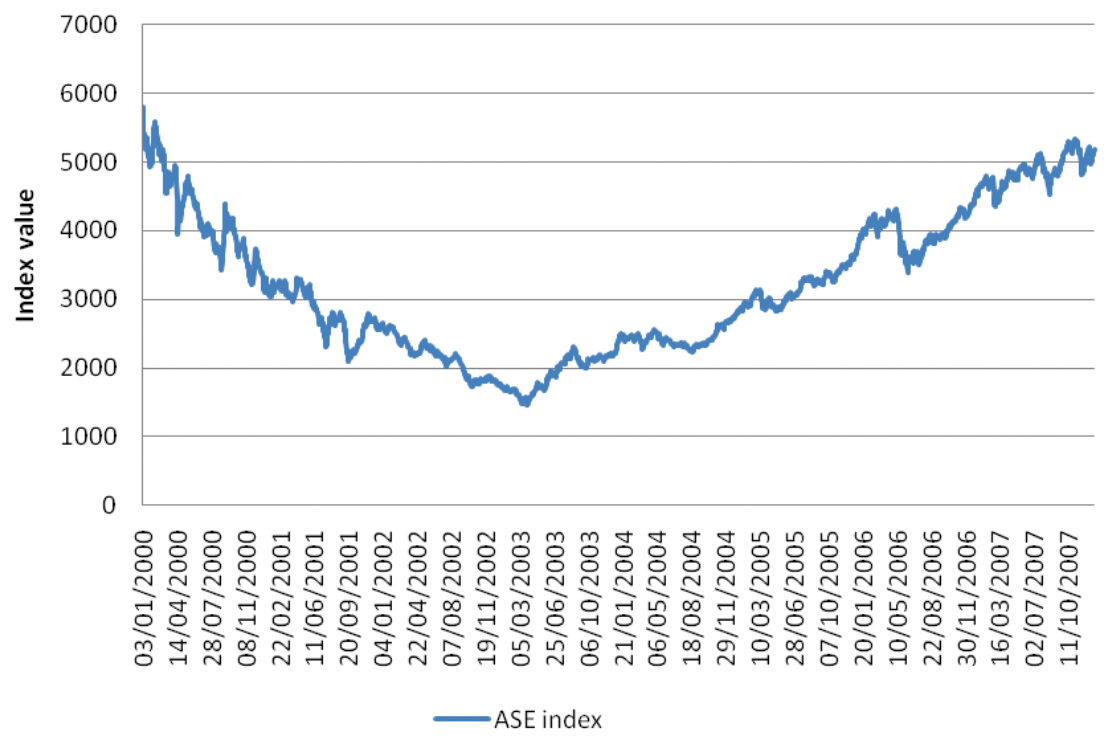

Fig. 1. ASE index over our sample period.

The sample ends as the first shock waves of the recent financial crisis were being felt. As such the study captures the Greek market in a period of relative tranquility between a dramatic boom and a later even more spectacular bust.

Table 1 gives some summary statistics for some of the most basic data entering our tests that is earnings-per-share changes and price responses to those changes on the days following their announcement. As can be seen earnings (per-share) changes show considerable losses with some large lossmaking companies entering our sample. But, the average earnings surprise and the stock market response to those announcements is very small, regardless of whether that response is measured over a 3 or 10-day period.

Table 1. Summary statistics for ASE sample 2001-2007.

\begin{tabular}{lccccl}
\hline Variable & $\mathrm{N}$ & Mean & $\sigma$ & Min & Max \\
\hline$\Delta$ actual EPS & 520 & -0.075 & 1.079 & -19.73 & 9.96 \\
Surprise $_{t s}$ & 227 & -0.003 & 0.128 & -0.570 & 1 \\
Surprise $_{\text {for }}$ & 240 & -0.0004 & 0.005 & -0.031 & 0.023 \\
Raw return 3-day $(0,+3)$ pead & 323 & 0.002 & 0.026 & -0.176 & 0.098 \\
Raw return 10-day $(0,+10)$ pead & 322 & -0.005 & 0.032 & -0.187 & 0.102 \\
\hline
\end{tabular}

Note: Surprise $_{\text {ts }}$ is as constructed in Eq. (1) of text.

Surprise $_{\text {for }}$ is as constructed in Eq. (2) of text. 
We use a short-window of three days $((0,+3)$, denoted pead +3 in figures $)$ and a longer window of two weeks or 10 trading days $((0,+10)$, denoted pead +10 in figures), after the earnings announcement to capture the stock market response to announced earnings. We use the two earnings surprise benchmarks described above (see Eqs. (1) and (2)).

The data we use in the study windsorises both earnings surprises and price changes at $100 \%$ of value. It is clear from both Table 1 and Fig. 2 that the time-series earnings benchmark displays far greater dispersion. So, we focus on the analysts' forecasts benchmark $\left(\right.$ Surprise $_{\text {for }}$ ) when reporting our results.

\subsection{The joint distribution of price responses and earnings surprises}

Figures 2 and 3 present scatter plots for the two earnings surprise metrics employed against a raw stock price buy and hold return for the three days following the earnings announcement $(0,+3)$. At such short windows the controls used to capture risk matters far less unless we anticipate strong riskshifts clustered around the earnings announcement itself. Comparing Figs. 2 and 3, it becomes obvious the extent to which the relationship between 3-day price responses and earnings surprises are influenced by outliers, even after

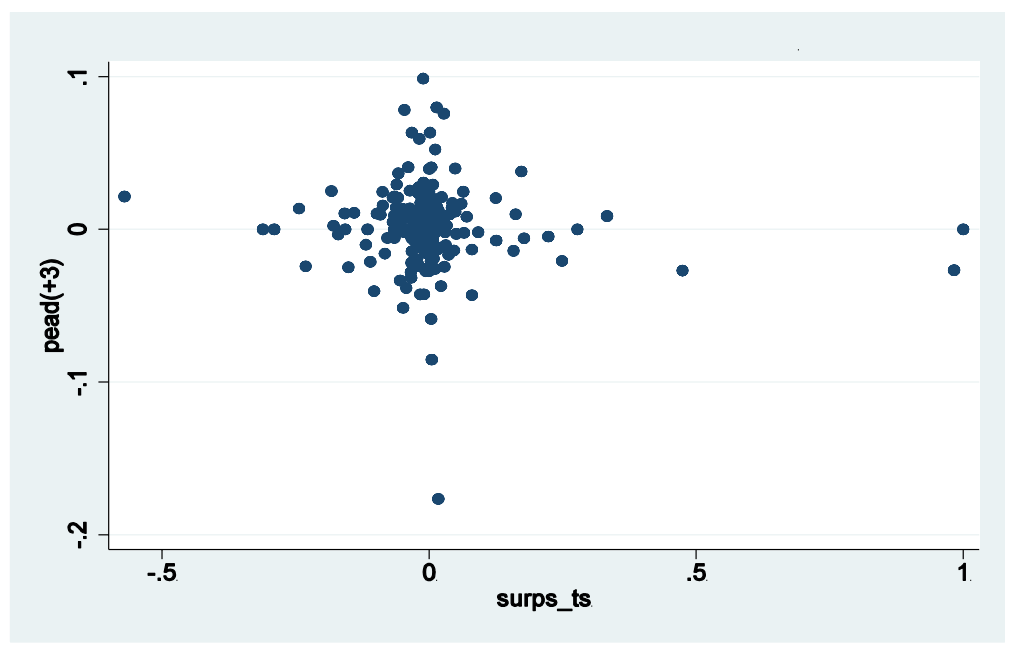

Fig. 2. Plot of earnings surprise versus 3-day PEAD using outstanding time-series benchmark.

Note: The measure of stock performance used here is simply raw stock returns without any risk adjustment for days $(0,+3)$. The earnings surprise benchmark used here is the consensus analyst forecast benchmark of Eq. (2) in text for Figs. 2 and 3, and the time-series benchmark of Eq. (1) in text. 


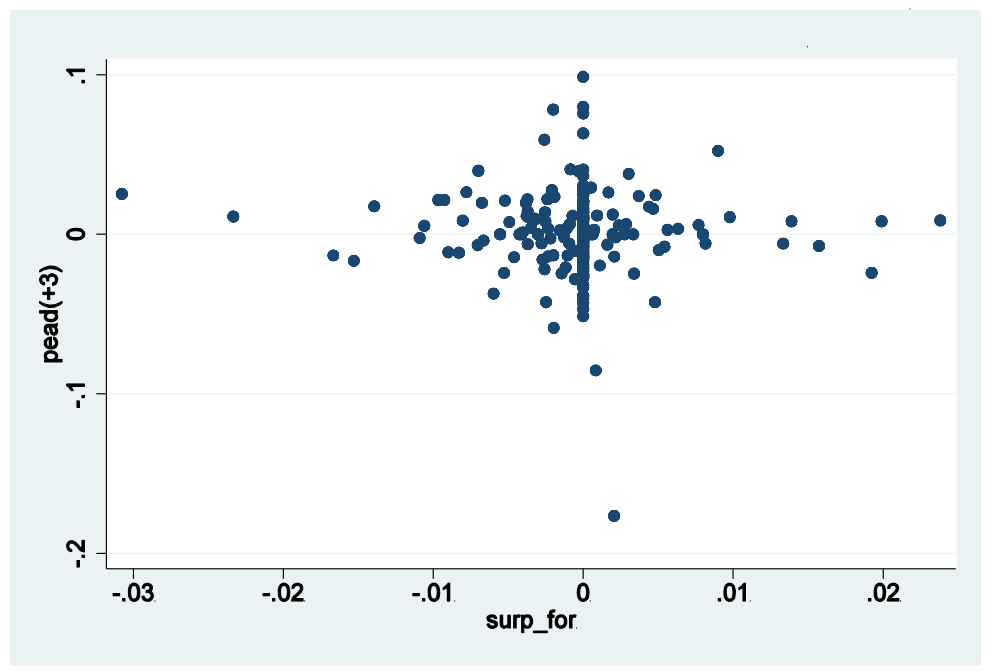

Fig. 3. Plot of earnings surprise versus 3-day PEAD using outstanding analyst forecast benchmark.

Note: The measure of stock performance used here is simply raw stock returns without any risk adjustment for days $(0,+3)$. The earnings surprise benchmark used here is the consensus analyst forecast benchmark of Eq. (2) in text for Fig. 3 and the time-series benchmark of Eq. (1) in Fig. 2.

windsorizing surprises where the error in predicting earning-per-share exceeds a $100 \%$ of price. ${ }^{4}$

While earnings surprises are usually almost zero, as a percentage of price, on either measure the reliance on a few large surprises in absolute value is far greater in the case of time-series earnings benchmarks in the Greek market.

Since macroeconomic conditions vary so much with the business cycle Figs. 4 and 5 plot median and mean values for earnings surprises and price responses, as measured by raw stock price buy and hold returns, across the years of our sample using the longer 10-day window for raw returns and the forecast-based earnings-surprise measure $(\operatorname{pead}(0,+10)$ against Eq. (2)'s metric, denoted Surprise ${ }_{\text {for }}$ ). Examining both plots the volatility of response to earning-surprises across yearly sub-samples is very clear.

Regardless of the measure of central tendency in returns used the 2002 average price response to announced earnings is strongly negative, suggesting a far higher earnings figure than that announced in that year was expected. Perhaps this indicates the presence of some sort of "earnings bath" taken prior to the need to backward reconcile accounts under IFRS in

\footnotetext{
${ }^{4}$ We windsorize data points to hold earnings surprises at $100 \%$ of the absolute value of the current price-earnings ratio.
} 


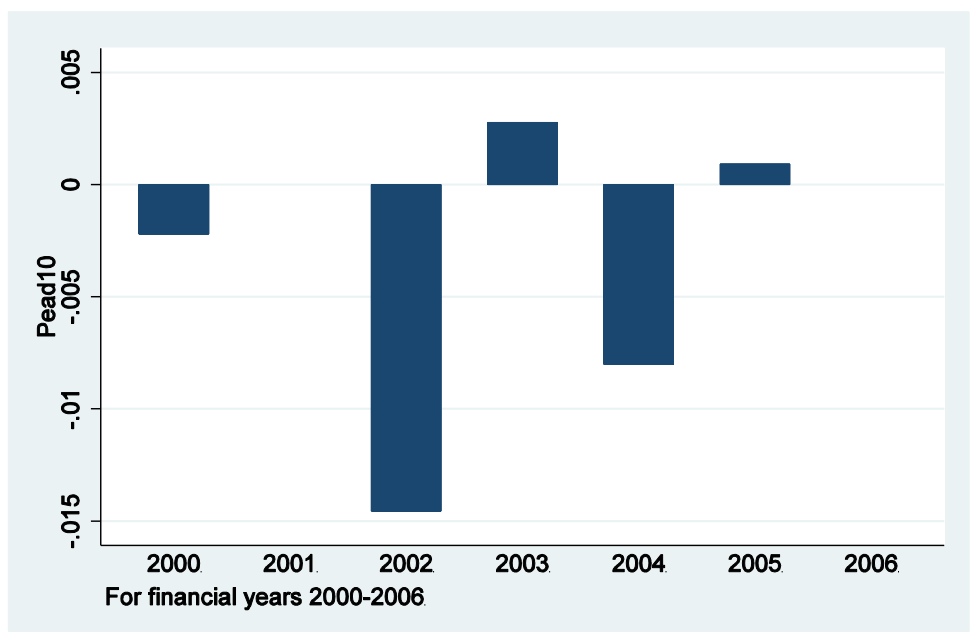

Fig. 4. Figure median 10-day CAR to earnings surprise using Surp_for measure of earnings surprise.

Note: The earnings surprise benchmark used here is the consensus analyst forecast benchmark of Eq. (2) in text. In Fig. 4, the measure of stock performance used is simply the median raw stock returns for days $(0,+10)$ and the comparable mean calculation in Fig. 5.

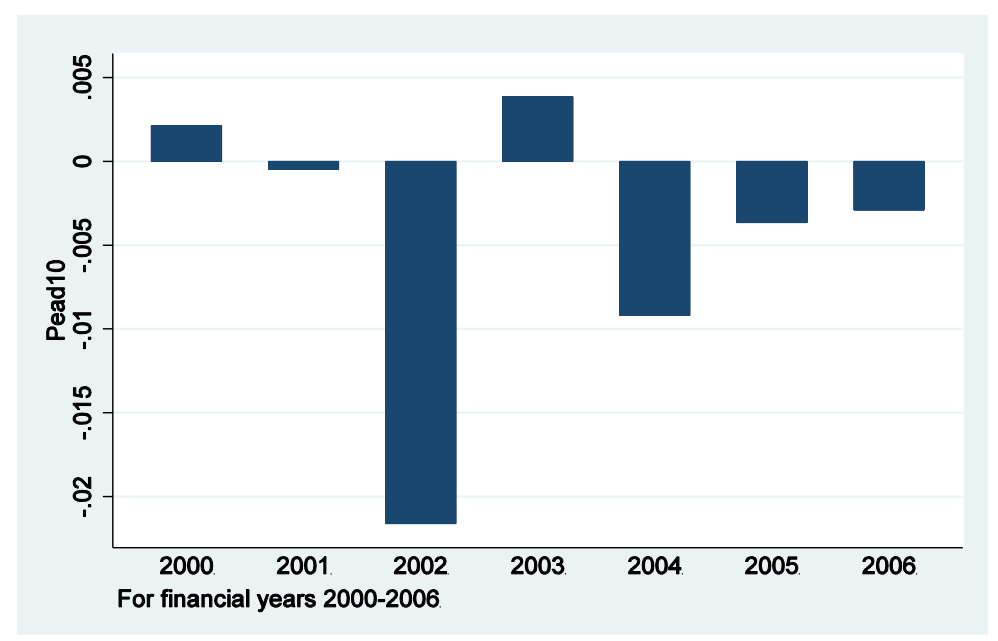

Fig. 5. Figure mean 10-day CAR to earnings surprise using Surp_for measure of earnings surprise.

Note: The earnings surprise benchmark used here is the consensus analyst forecast benchmark of Eq. (2) in text. In Fig. 4, the measure of stock performance used is simply the median raw stock returns for days $(0,+10)$ and the comparable mean calculation in Fig. 5. 
anticipation of final IFRS compliance in 2005. For both mean and median returns there is a clear shift to investor optimism about earnings around 2003, which accords with the revived fortunes of the Athens index plotted in Fig. 1. Li and Huang (2013) confirm that managerial optimism intensifies the practice of earnings management using a sample of Taiwanese companies. It is clear something fairly dramatic happened to earnings expectations, and market responses to their fulfilment or otherwise, in the period following 2003. It is likely that this structural break also impacted on recorded PEAD in Greece.

The most obvious motivation for this change in earnings transparency was the implementation of IFRS by Greece at that time. The Olympic Games were also scheduled to arrive in Athens, its original home, in 2004. While IFRS was only adopted by EU states on the 1st January 2005, the EU also required backward reconciliation of published accounts for two years. So, our sample brackets a major market reversal reflecting both EU membership and the adoption of IFRS standards more specifically.

\section{Evidence of PEAD in Greece}

Figure 6 gives an initial impression of the scale of observed PEAD in our Greek sample once we split sample firms into good and bad news about earnings portfolios, pooling all sample year observations, and initially using

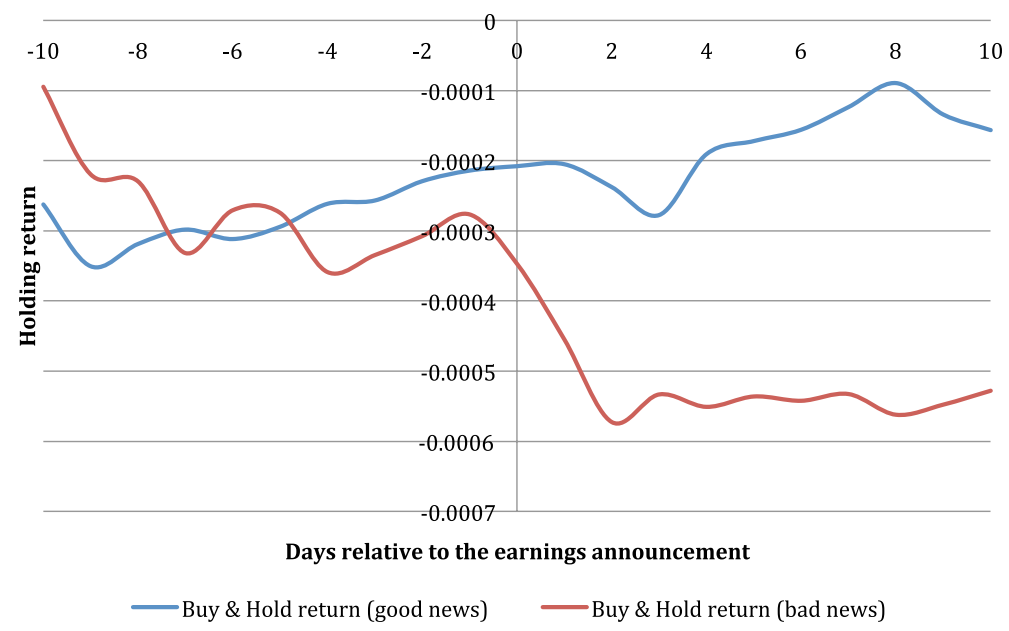

Fig. 6. PEAD in ASE for whole sample with market-adjusted return benchmark.

Note: PEAD over the whole sample period using the market-adjusted return, calculated according to the buy and hold metric. The earnings surprise benchmark used here is the consensus analyst forecast benchmark of Eq. (2) in text. 
just the buy and hold market-adjusted returns to capture the market response to an earnings surprise. Here, earnings surprises are measured by the deviation of the consensus forecast of earning-per-share issued in the previous month and the announced value (Surprise $_{\text {for }}$, the benchmark given in Eq. (2). We present our results for an event window of minus 10 days to plus 10 days. Clear evidence exists of earnings anticipation, amongst both the good and bad news portfolios, but little overall drift is present. The buy and hold return plots of the good and bad news portfolios do however diverge substantially in the 10 days following the earnings announcement.

The Athens exchange market is itself an institution undergoing huge transformation in these years and averaging over the whole of our sample period may be unwise as Figs. 4 and 5 suggest.

Comparing the pre-and post-IFRS regime the concentration of PEAD in the period after IFRS were introduced is striking. After the introduction of IFRS the gap between good and bad news portfolio returns is both large and clearly present, even 10 days after the earnings announcement.

The gap between good and bad news portfolios is consistently large and invariant around the earnings announcement before or after IFRS's introduction. But, before the introduction of IFRS the separation of good and bad news about earnings portfolios largely evaporates just before the earnings announcement date. Earnings anticipation post IFRS seems to have not greatly changed, but the market impact of an earnings announcement itself seems to have been greatly enhanced by the introduction of IFRS, at least when we use the buy and hold market-adjusted return benchmark for returns as a performance benchmark. This reflects the diminished predictability of earnings following the implementation of IFRS, which reduced the conservatism of reported earnings in Greece, and the greater volatility of earnings induced by "fair-value" revaluations of sample companies' balance sheets.

\subsection{Regression based tests}

Perhaps the most standard test of PEAD in the market-based literature are regressions of stock market responses upon earnings surprise metrics. Of course such tests suggest a linearity and normality of distribution our data do not have (even after the removal of outliers). Nevertheless to make our work comparable with that of major prior studies of PEAD we present such regression results in Table 2. This table presents results for a regression of investor returns in the 10 days following an earning-announcement $(0,+10)$, 
Table 2. PEAD regression using 10 day buy and hold abnormal returns using equivalent size-quartile benchmark.

\begin{tabular}{|c|c|c|c|c|}
\hline Variable & Coefficient & White $t$-Value & $\mathrm{N}$ & R-Squared \\
\hline \multicolumn{5}{|c|}{ Whole period $2000-2006$} \\
\hline Surprise $_{\text {for }}$ & -0.0033 & 0.002 & 300 & 0.003 \\
\hline Constant & -0.0003 & 0.9 & & \\
\hline \multicolumn{5}{|c|}{ Pre IFRS 2000-2004 } \\
\hline Surprise $_{\text {for }}$ & -0.002 & -0.7 & 184 & 0.0001 \\
\hline Constant & 0.0008 & 0.15 & & \\
\hline \multicolumn{5}{|c|}{ Post IFRS 2005-2006 } \\
\hline Surprise $_{\mathrm{for}}$ & 0.003 & 6.12 & 116 & 0.054 \\
\hline Constant & -0.002 & -0.41 & & \\
\hline
\end{tabular}

where $R_{i, t}$ is the return on the $i$ th stock at $\mathrm{t}, R_{s, t}$ is the return on an average stock in the same size quartile in time t, $E_{i, t-1}$ $\left[X_{i t}\right]$ is the forecast of earnings, $X_{i, t}$, at month $t$ formed a month before.

adjusted by the average return to firms in the same size quartile, employing the analysts' forecast based earnings-surprise metric, Surprise $_{\text {for }}$ (as given by Eq. (2)).

The regression confirms the weak evidence of PEAD's presence during our whole sample period, but also shows strong evidence of its clustering in the post-IFRS period. Note that while the post-IFRS coefficient on the earnings surprise is strongly significant its size is small, suggesting the ability to profitably trade on this anomaly may be somewhat constrained given the size of spreads in the Athenian market.

\subsection{PEAD with Fama-French 3-factor controls}

The Fama-French benchmark has now become the standard technology for controlling for company differences (see Fama and French, 1993). Ken French's excellent web page provides estimates of the relevant "risk" factors for many countries in Europe and elsewhere. Sadly, factors for the Greek market are not downloadable from French's website. So, we construct our own estimates here for the ASE based on size and market to book quartiles. We take the average return on the smallest quartile of stocks quoted on the ASE, by market capitalization in each prior year's July, from that of the largest to yield our size factor, small minus big (SMB). We take the average return on the lowest market-to-book quartile of stocks (i.e., those facing the 


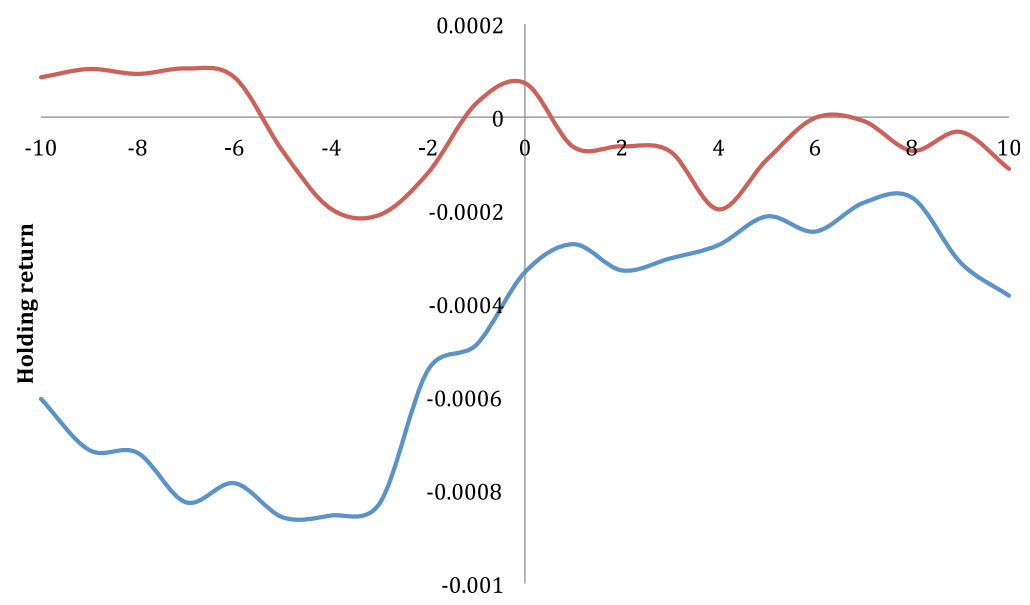

Days relative to earnings announcement

- Buy \& Hold return to good news portfolio — Buy \& Hold return to bad news portfolio

Fig. 7. PEAD in ASE pre IFRS using market adjusted benchmark.

Note: PEAD over the whole sample period using the market-adjusted return, calculated according to the buy and hold metric. The earnings surprise benchmark used here is the consensus analyst forecast benchmark of Eq. (2) in text.

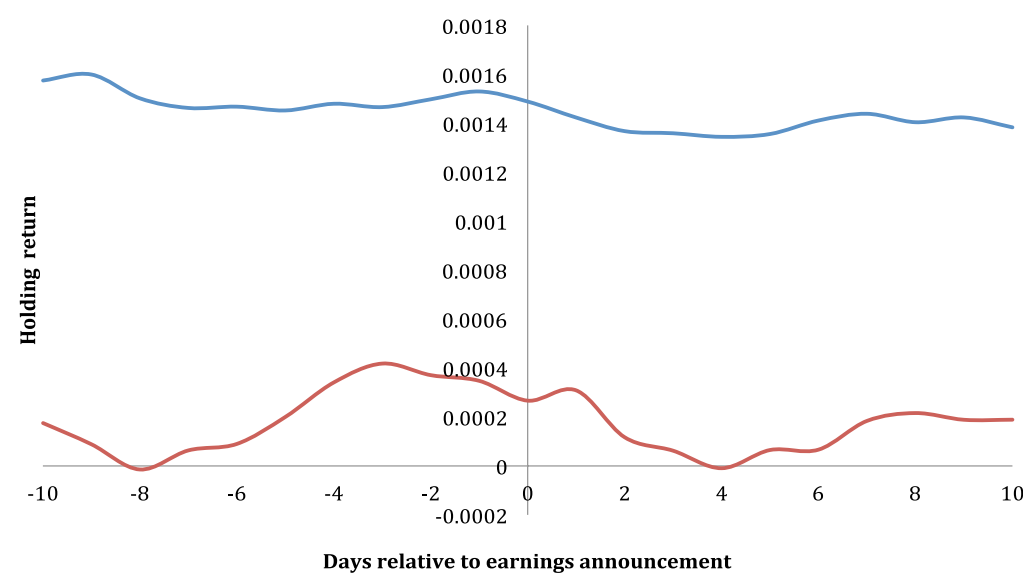

Buy \& Hold returns for good news portfolio — Buy \& Hold returns for bad news porfolio

Fig. 8. PEAD in ASE post-IFRS period using market-adjusted return benchmark.

Note: This figure PEAD over the post-IFRS period using the market-adjusted return benchmark using a buy and hold metric. The earnings surprise benchmark used here is the consensus analyst forecast benchmark of Eq. (2) in text. 


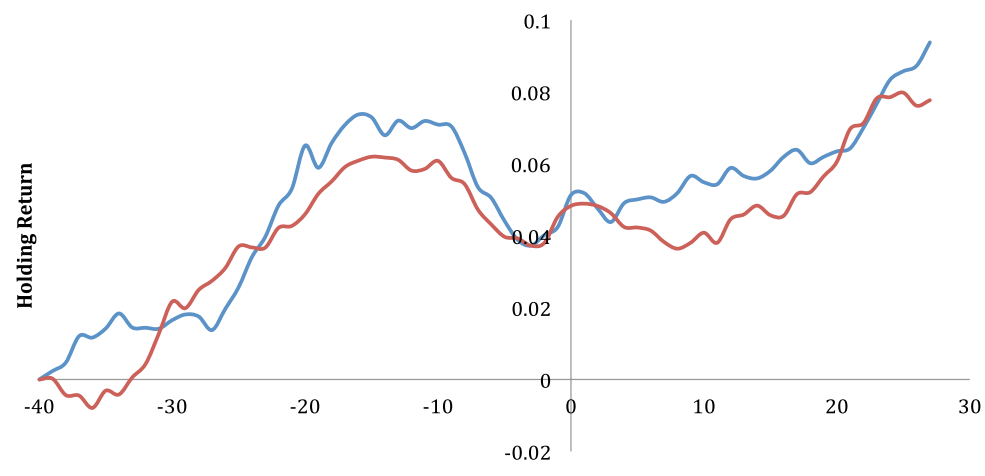

Days relative to earnings announcement

Buy \& Hold return for good news portfolio — Buy \& Hold return for bad news porfolio

Fig. 9. PEAD in ASE for whole sample using Fama-French benchmark.

Note: This figure PEAD over the whole sample period using the Fama-French 3-factor benchmark of Eq. (4) using the buy and hold return metric of Eq. (3).

highest liquidation risk) quoted on the ASE, ranked in the July of the previous year, from the average return on the highest market-to-book quartile (facing the least liquidation risk) to yield our value factor, high minus low (HML). The resulting estimates of PEAD, relative to this 3-factor benchmark, are reproduced in Figs. 9-11. Given the sharper definition of PEAD we uncover using this benchmark we extend the observation window to 30 days either side of the earnings announcement day.

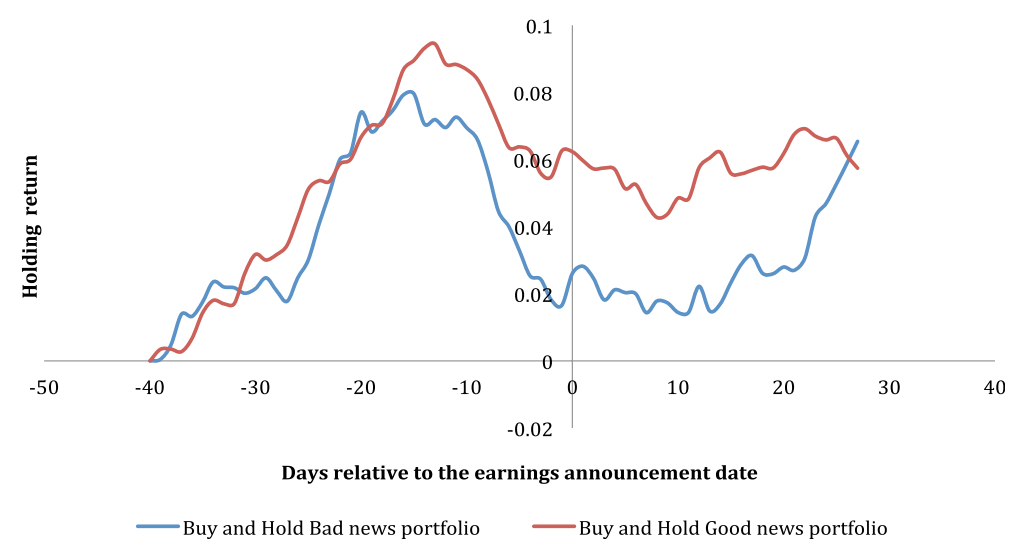

Fig. 10. PEAD in ASE pre-IFRS using the Fama-French benchmark.

Note: PEAD over the pre-IFRS and post-IFRS period using the Fama-French 3-factor benchmark of Eq. (4) using the buy and hold return metric of Eq. (3) The earnings-surprise benchmark used here is the consensus analyst forecast benchmark of Eq. (2) in the text. 


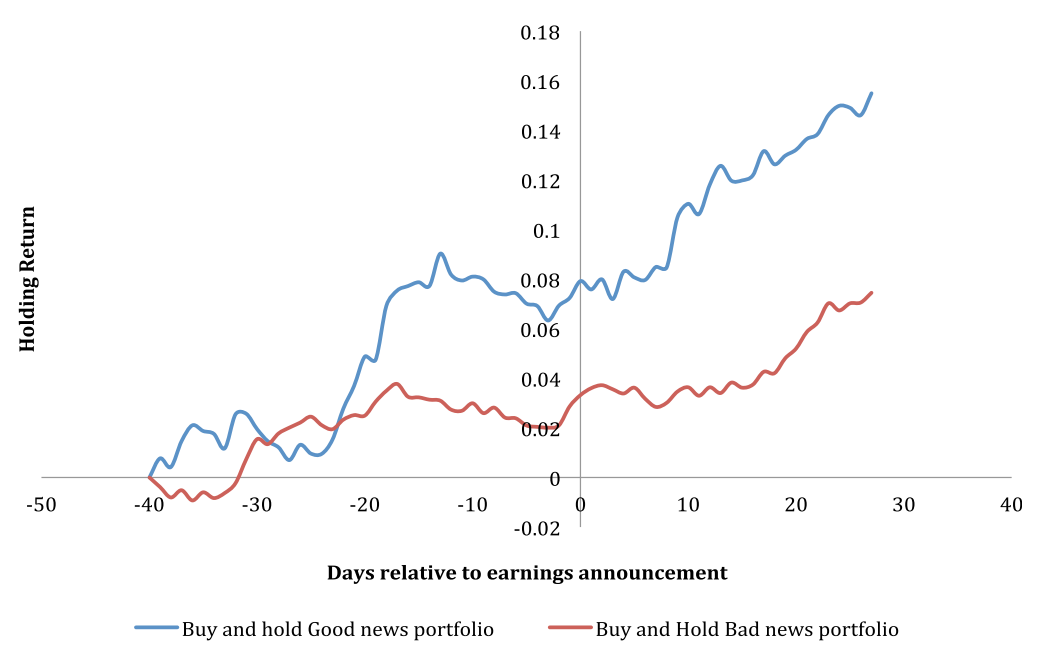

Fig. 11. PEAD in ASE post-IFRS period using Fama-French benchmark.

Note: PEAD over the pre-IFRS and post-IFRS period using the Fama-French 3-factor benchmark of Eq. (4) using the buy and hold return metric of Eq. (3) The earnings-surprise benchmark used here is the consensus analyst forecast benchmark of Eq. (2) in the text.

As with the previous benchmarks we find some evidence of PEAD in the Greek market in our overall sample, but find it to be far more sharply defined in the post-IFRS period, 2005-2006. Once again investor anticipation of the earnings announcement seems strong both before and after the introduction of IFRS. This suggests the "earnings surprise" we study may not be that surprising to the market at all because insiders have anticipated it in their trades.

\section{Conclusions}

The results of our paper confirm the presence of PEAD in the Greek market and suggest its scale intensified after the introduction of IFRS in 2005, although most Greek companies issued IFRS compliant financial accounts from 2003 onwards. A factor clearly undermining these conclusions is the strong presence of earnings anticipation in the data, suggesting the earnings announcement may not be hugely surprising to most market professionals for the average company. Nevertheless our tests, using a wide-range of benchmarks for both abnormal returns and earnings surprises suggest PEAD is alive, well and growing of late in the Greek market. Our somewhat counterintuitive conclusion is that the introduction of IFRS into the Athens market in 2005 sharpened the presence and persistence of observed PEAD in that market. 
While the finding that IFRS has reduced the informational efficiency of the Greek equity market at first seems anomalous it does reflect some of the practicality of IFRS reform. While before IFRS Greek GAAP was highly conservative and largely devoted to minimizing taxable profit this all changed with the implementation of IFRS. Compliance required the application of "fair-value" asset revaluations in an era of surging stock markets in Athens. This made earnings both less conservative and crucially far less predictable prior to their announcement. In this context, PEAD was able to grow as investors struggled to interpret the meaning of freshly IFRS complaint earnings.

\section{References}

Athianos, S, A Vazakidis and N Dritsakis (2005). Financial statement effects of adopting international accounting standards. Working Paper Series, University of Macedonia.

Ball, R and P Brown (1968). An empirical evaluation of accounting numbers. Journal of Accounting Research, 6(Supplement), 159-179.

Barber, B and J Lyon (1997). Detecting long-run abnormal stock returns: The empirical power and specification of test statistics. Journal of Financial Economics, 43(3), 341-372.

Battalio, R and R Mendenhall (2005). Earnings expectations, investor trade size and anomalous returns around earnings announcements. Journal of Financial Economics, 77(2), 289-319.

Baralexis, S (2008). Creative accounting in small advancing countries: The Greek case. Managerial Auditing Journal, 19(3), 440-461.

Bernard, V (1993). Stock price reactions to earnings announcements: A survey of recent anomalous evidence and possible explanations. In Advances in Behavioural Finance, R Thaler (ed.). New York: Sage.

Bernard, V and J Thomas (1989). Post-earnings-announcement drift: Delayed price response or risk premium? Journal of Accounting Research, 27(Supplement), $1-48$.

Bernard, V and J Thomas (1990). Evidence that stock prices do not fully reflect the implications of current earnings for future earnings. Journal of Accounting and Economics, 13, 305-340.

Bhattacharya, U, H Daouk and M Welker (2003). The world price of earnings opacity. Accounting Review, 78(3), 641-678.

Bird, R, D Choi and D Yeung (2014). Market uncertainty, market sentiment and post earnings announcement drift. Review of Quantitative Finance and Accounting, 43(1), 45-73.

Boonlert U-Thai, K, G Meek and S Nabar (2006). Earnings attributes and investor protection. International Journal of Accounting, 41(4), 327-367.

Caramanis, C (1999). International accounting firms versus indigenous auditors: Intra professional conflict in the Greek auditing profession 1990-1993. Critical perspectives on Accounting, 10(2), 153-196. 
Cohen, D, A Dey, T Lys and S Sunder (2007). Earnings announcement premia and the limits to arbitrage. Journal of Accounting and Economics, 43(2-3), 153-180.

Dasilas, A and S Leventis (2011). Stock market reaction to dividend announcements: Evidence from the Greek stock market. International Review of Economics and Finance, 20(2), 302-311.

Daske, H, H Luzi, C Leuz and R Verdi (2008). Mandatory IFRS around the World: Early evidence and the economic consequences. Journal of Accounting Research, 46(5), 1085-1142.

Dokery, E and M Kavassanos (1995). The efficient market hypothesis. In Empirical Studies of the Greek Stock Exchange, G Karathanasis and M Glezakos (eds.). Athens: Papasisi.

Fama, E (1998). Market efficiency, long-term returns and behavioral finance. Journal of Financial Economics, 49(3), 283-306.

Fama, E and K French (1993). Common risk factors in the returns on stocks and bonds. Journal of Financial Economics, 33(1), 3-56.

Florou, A and G Argiris (2007). Benchmarking Greek corporate governance against different standards. Corporate Governance, 15(5), 979-998.

Kao, L (2007). Does investors' sophistication affect persistence and pricing of discretionary accruals?. Review of Pacific Basin Financial Markets and Policies, 10(1), 33-50.

Karampinis, N and D Hevas (2011). Mandating IFRS in an unfavourable environment: The greek experience. International Journal of Accounting, 46(3), 304-332.

Leuz, C, D Nanda and P Wysocki (2003). Earnings management and investor protection: An international comparison. Journal of Financial Economics, $69(3), 505-527$.

Li, I and J Huang (2013). The moderating effect of family control on the relation between managerial overconfidence and earnings management. Review of Pacific Basic Financial Markets and Policies, 16(2), 1-33.

Liu, W, N Strong and X Xu (2003). Post-earnings announcement drift in the UK. European Financial Management, 9(1), 89-116.

Liu, C, L Yao and M Yao (2012). Value relevance change under International Accounting Standards: An empirical study of Peru. Review of Pacific Basic Financial Markets and Policies, 15(2), 1-17.

Lyon, J, B Barber and C Tsai (1999). Improved methods for tests of long-run returns. Journal of Finance, 54(1), 165-201.

Phylaktis, K, M Kavussanos and G Manalis (1999). Price limits and stock market volatility in the Athens stock exchange. European Financial Management, 5(1), 69-84.

Pope, P and S McLeay (2011). The European IFRS experiment: Objectives, research challenges and some early evidence. Accounting \& Business Research, 41(3), 233-266.

Vafeas, N, L Trigeorgis and X Georgiou (1998). The usefulness of earnings in explaining stock returns in an emerging market: The case of Cyprus. European Accounting Review, 7(1), 105-124. 
Vazakidis, A and S Athianos (2010). Measuring investors' reactions to the adoption of International Financial Reporting Standards in Greece, using a market-based model. American Journal of Economics and Business Administration, 2(1), 103-112.

Verriest, A, A Gaeremynck and D Thornton (2013). The Impact of Corporate Governance on IFRS adoption choices. European Accounting Review, 22(1), $39-77$.

Wang, Z (2014). Measuring investors' assessment of earnings persistence: do investors see through smoothed earnings? Review of Quantitative Finance and Accounting, 42(4), 691-708. 